\title{
SPECIATION OF CARBON AND SELECTED METALS IN SPENT MUSHROOM SUBSTRATES
}

\author{
Dorota Kalembasa, Marcin Becher \\ Chair of Soil Science and Plant Nutrition \\ Siedlce University of Natural Science and Humanities
}

\begin{abstract}
Increasing amounts of spent mushroom substrate in the Siedlce region and the unsolved problem of its disposal has encouraged researchers to study its properties and, subsequently, the possibility of its utilisation as fertiliser. Samples of (fresh) substrate after 6 -week cultivation of the white mushroom Agaricus bisporus in two modern cultivation halls were used as the studied material. The determined parameters included its $\mathrm{pH}$ and the content of dry matter, ash, mineral nitrogen as well as total carbon and nitrogen. The main aim of the study was to determine the speciation of organic carbon and metals in spent mushroom substrates. To this end, their sequential extraction was carried out by the method described by $\mathrm{He}$ et al. (1995), recommended for materials with a high organic matter content. The extraction procedure yielded six operational fractions of carbon and metals and separated the humic substances into fractions of fulvic and humic acids and metals bound with them. Sequential application of extraction reagents of increasing ability to extract carbon and metal from compounds $\left(\mathrm{H}_{2} \mathrm{O} \rightarrow \mathrm{KNO}_{3} \rightarrow \mathrm{Na}_{4} \mathrm{P}_{2} \mathrm{O}_{7} \rightarrow \mathrm{NaOH} \rightarrow \mathrm{HNO}_{3} \rightarrow\right.$ aqua regia) allowed us to assess the potential bioavailability and resistance to biodegradation, as well as current and potential hazards to the environment (phytoavailability, mobility). It has been found that spent mushroom substrate could be recommended as fertiliser because it can enrich soils with organic matter. The largest amounts of carbon (62\%) were found in the stable residual fraction, whereas the bioavailable fractions contained about $10 \%$ of carbon. Concentrations of metals $(\mathrm{Mg}, \mathrm{Ca}, \mathrm{Fe}, \mathrm{Mn}, \mathrm{Ba}, \mathrm{Sr}, \mathrm{Zn}, \mathrm{Cu}, \mathrm{Ni}, \mathrm{Cr}, \mathrm{Pb}$ ) in the material were variable, but most metals were found in the fraction strongly bound with organic and mineral compounds $(30.8-80.6 \%)$. Ca, $\mathrm{Mg}, \mathrm{Mn}, \mathrm{Sr}, \mathrm{Fe}$, and $\mathrm{Zn}$ were predominantly bound with mobile fulvic acids, whereas $\mathrm{Cu}, \mathrm{Ni}, \mathrm{Ba}$, and $\mathrm{Pb}$ - with more stable humic acids.
\end{abstract}

Key words: spent mushroom substrate, sequential extraction, carbon fractions, metal fractions.

prof. dr hab. Dorota Kalembasa, Chair of Soil Science and Plant Nutrition, Siedlce University of Natural Science and Humanities, 08-110 Siedlce, Prusa 14, e-mail: kalemasa@uph.edu.pl 


\title{
SPECJACJA WĘGLA I WYBRANYCH METALI W PODLOŻU \\ PO UPRAWIE PIECZARKI
}

\begin{abstract}
Zwiększająca się ilość podłoża po uprawie pieczarek w rejonie siedleckim oraz nierozwiązany problem jego utylizacji sprowokowały do badań jego właściwości, a w perspektywie także nawozowego wykorzystania. Materiał badawczy stanowiły próbki podłoża (świeżego) po 6-tygodniowej uprawie pieczarki białej Agaricus bisporus z dwóch nowoczesnych hal uprawowych w regionie siedleckim. Oznaczono w nich pH, zawartość suchej masy, popiołu, azotu $\mathrm{w}$ formach mineralnych oraz całkowita zawartość węgla i azotu. Celem badań było określenie specjacji węgla związków organicznych i metali w badanych podłożach popieczarkowych z zastosowaniem ich sekwencyjnej ekstrakcji, na podstawie metody $\mathrm{HE}$ i in. (1995) - polecanej dla materiałów o wysokiej zawartości materii organicznej. Procedura ekstrakcyjna umożliwiła wydzielenie 6 frakcji operacyjnych węgla i metali oraz rozdzielenie substancji humusowych na frakcję kwasów fulwowych i huminowych oraz metale $\mathrm{z}$ nimi powiązane. Sekwencyjne zastosowanie odczynników ekstrakcyjnych o zwiększających się właściwościach wydzielania węgla i metali w związkach $\left(\mathrm{H}_{2} \mathrm{O} \rightarrow \mathrm{KNO}_{3} \rightarrow \mathrm{Na}_{4} \mathrm{P}_{2} \mathrm{O}_{7} \rightarrow \mathrm{NaOH}\right.$ $\rightarrow \mathrm{HNO}_{3} \rightarrow$ woda królewska) pozwoliło ocenić potencjalna biodostępność i odporność na biodegradację, a w przypadku metali ciężkich także aktualne i potencjalne zagrożenie dla środowiska (fitoprzyswajalność, mobilność). Stwierdzono, iż podłoże po uprawie pieczarki powinno być zalecane do nawozowego stosowania, gdyż ma znaczny potencjał wzbogacania gleb w związki organiczne. Najwięcej węgla $(62 \%)$ było związane ze stabilną frakcja rezydualna, a we frakcjach biodostępnych - ok. 10\%. Zawartość metali $(\mathrm{Mg}, \mathrm{Ca}, \mathrm{Fe}, \mathrm{Mn}, \mathrm{Ba}$, $\mathrm{Sr}, \mathrm{Zn}, \mathrm{Cu}, \mathrm{Ni}, \mathrm{Cr}, \mathrm{Pb})$ w badanym materiale była zróżnicowana, przy czym większość z nich występowała we frakcji mocno związanej ze związkami organicznymi i mineralnymi $(30,8$ $-80,6 \%$ ). Z mobilnymi kwasami fulwowymi były związane w większych ilościach $\mathrm{Ca}, \mathrm{Mg}$, $\mathrm{Mn}, \mathrm{Sr}, \mathrm{Fe}, \mathrm{i} \mathrm{Zn}$, a z bardziej stabilnymi kwasami huminowymi - $\mathrm{Cu}, \mathrm{Ni}, \mathrm{Ba}, \mathrm{i} \mathrm{Pb}$.
\end{abstract}

Słowa kluczowe: podłoże popieczarkowe, ekstrakcja sekwencyjna, frakcje węgla, frakcje metali.

\section{INTRODUCTION}

The cultivation of mushrooms in Poland has been developing well in the recent years and concentrated in the region near Siedlce and Losice, where latest production technologies are implemented. With the production output of 250-300 thousand tonnes, Poland is the largest producer in Europe and the third largest one in the world. Mushroom substrate consists of mainly straw and poultry litter (frequently with added urea, gypsum, coconut fibre, highmoor peat and soybean protein). The surface cover is made of lowmoor peat with dolomite, defecation lime or meadow chalk. Modern mushroom farms cultivate mushroom mostly on phase III substrate, i.e. grown-through with mycellium outside a cultivation hall, during one of the stages of its production. Spent mushroom substrate (substrate and cover grown-through with mycelium hyphae) is obtained after 6 weeks of intensive cultivation and two or three harvests of mushrooms. The local aggregation of mushroom farming, with consequently large amounts of spent sub- 
strate, forces us to look for methods of some rational utilisation of spent substrate which would be safe to the environment. Uncontrolled dumping in the neighbourhood of large mushroom farms poses a risk that large amounts of bioelements will migrate outside prisms so that the surrounding area will become eutrophic. Rational utilisation of spent mushroom substrate and using it as fertiliser seems to be the most appropriate form of its disposal, as it will improve the balance of nutrients, especially in low-humus soils (a disadvantageous balance of organic matter). The results of scientific research have indicated that this solution is possible, especially because of relatively high concentrations of nutrients in spent substrate (STEWART et al. 1998, Zmora-Nahum et al. 2007, Jordan et al 2008, Kalembasa, MajchrowsKa-Safaryan 2009a,b, Medina et al. 2009, Rutkowska et al. 2009). According to the principles of modern technology, spent mushroom cultivation substrate is disinfected thermally at $70^{\circ} \mathrm{C}$, which restrains infestation of agricultural ecosystems with weed seeds and pathogens when mushroom substrate is used as fertiliser. The Polish literature does not contain any thorough reports on properties of organic waste, especially on speciation of metals bound with carbon compounds. This study is an attempt at rectifying the situation, particularly because the previous studies on metal speciation have not always taken into account the main components of substrates, i.e. organic matter.

The aim of the study was to evaluate selected properties and especially to determine the speciation of organic carbon and metals in substrate after 6 weeks of cultivation of white mushrooms, with respect to its later use as fertiliser.

\section{MATERIAL AND METHODS}

Samples of spent substrate after 6 weeks of cultivation of the white mushroom Agaricus bisporus from two modern cultivation halls in the Siedlce region were used as the studied material. The samples (covers and substrate, together called substrate) were taken at several points (from shelves at different height), after steam disinfection and before substrate with mushrooms was removed. Each averaged sample was analysed in a laboratory in three replications. Determinations included $\mathrm{pH}$ (potentiometrically) and mineral nitrogen (Min-N), by the distillation method, after extraction of samples with $1 \mathrm{~mol} \mathrm{KCl} \mathrm{dm}^{-3}$. Ash content was determined gravimetrically, following mineralisation in a muffle furnace (temp. $450^{\circ} \mathrm{C}$ ). For other analyses, samples were dried at $40^{\circ} \mathrm{C}$ and ground in an agate mill $(\mathrm{O}<0.25 \mathrm{~mm})$. Total carbon (TC) and nitrogen $(\mathrm{TN})$ content was determined with a Series II 2400 autoanalyser, manufactured by Perkin Elmer, with a thermal conductivity detector and acetanilide as the reference standard 
sxibstance. The results were calculated with reference to absolutely dry weight of the studied material, which was determined gravimetrically after drying the substrate at $105^{\circ} \mathrm{C}$.

Sequential extraction of organic carbon and metals partially bound with them was carried out by the method developed by He et al. (1995), recommended for materials with a high organic content. The extraction procedure isolates six operational fractions of carbon and metals and separates humic substances into fractions of fulvic and humic acids (Table 1). The extraction was conducted in polypropylene centrifuge flasks on a shaker-type agitator (soil sample weight-to-extraction solution ratio was 1:10) for $24 \mathrm{~h}$. The solutions were clarified by centrifuging for 30 minutes $(12,000 \mathrm{rpm})$ and vacuum filtering. During the stage of extraction of humic substances, potassium sul-

Table 1

Fractions of organic carbon compounds and metals isolated by the modified method developed by $\mathrm{He}$ et al. (1995)

\begin{tabular}{|c|c|c|}
\hline Fraction & Operational fraction & Extraction reagent \\
\hline F1 & water-soluble & deionised water $\mathrm{H}_{2} \mathrm{O}$ \\
\hline F2 & $\begin{array}{l}\text { exchangeably-bound with the solid phase, } \\
\text { mainly by electrostatic forces }\end{array}$ & $\begin{array}{l}\text { potassium nitrate }(\mathrm{V}) \\
1 \mathrm{~mol} \mathrm{KNO}_{3} \mathrm{dm}^{-3}\end{array}$ \\
\hline $\begin{array}{l}\text { F3 } \\
\text { F3 } \\
\text { FA } \\
\text { FA }\end{array}$ & $\begin{array}{l}\text { metals complexed with humic substances, } \\
\text { divided into fulvic and humic acids }\end{array}$ & $\begin{array}{l}\text { tetrasodium diphosphate }(\mathrm{V}) \\
0.1 \mathrm{~mol} \mathrm{Na}_{4} \mathrm{P}_{2} \mathrm{O}_{7} \mathrm{dm}^{-3}\end{array}$ \\
\hline $\begin{array}{l}\mathrm{F} 4 \\
\mathrm{~F} 4_{\mathrm{FA}} \\
\mathrm{F} 4_{\mathrm{HA}}\end{array}$ & $\begin{array}{l}\text { metals bound with humic substances, divided } \\
\text { into fulvic and humic acids }\end{array}$ & $\begin{array}{l}\text { sodium hydroxide } \\
0.1 \mathrm{~mol} \mathrm{NaOH} \mathrm{dm}\end{array}$ \\
\hline F5 & $\begin{array}{l}\text { metals strongly bound with organic and } \\
\text { mineral solid phase }\end{array}$ & $\begin{array}{l}\text { nitric }(\mathrm{V}) \text { acid } \\
4 \mathrm{~mol} \mathrm{HNO}_{3} \mathrm{dm}^{-3}\end{array}$ \\
\hline F6 & residual - post-extraction residue & $\begin{array}{l}\text { aqua regia } \\
\mathrm{HCl}: \mathrm{HNO}_{3}, \mathrm{v} / \mathrm{v}=3 / 1\end{array}$ \\
\hline
\end{tabular}

phate (VI) was added to the flocculate colloids. Some of the extract from humic substances $\left(\mathrm{Na}_{4} \mathrm{P}_{2} \mathrm{O}_{7}\right.$ and $\left.\mathrm{NaOH}\right)$ was acidified with $3 \mathrm{~mol} \mathrm{H}_{2} \mathrm{SO}_{4} \mathrm{dm}^{-3}$ to precipitate the humic acid fraction $(\mathrm{pH}=1.5)$; the effectiveness of separation of fulvic acids from humic acids was enhanced by centrifuging. Organic carbon content in the extracts was determined by the oxidative-titrimetric method (KALEMBASA, 1991). Carbon content in the residual fraction was determined as the difference with respect to the total content of the element; carbon content as humic acids was calculated as the difference between the amount in the extract (F3 and F4) and the amount in the fulvic acid fraction. Metal content in the extracts was determined with an inductively coupled plasma atomic emission spectroscope (ICP - AES, Optima 3200 RL manufactured by Perkin Elmer), after the solutions were mineralised with nitric (V) 
acid and hydrogen peroxide. Metal content in the humic acid fraction was calculated in the same manner as for carbon. The total metal content was calculated by adding up the content in all fractions (F1 - F6).

The extraction procedure was modified for carbon content determination in the solutions by the oxidative-titrimetric method. According to the original guidelines, large amounts of chlorine are introduced to the extraction system ( $\mathrm{KCl}$ solution with exchangeable fraction, $\mathrm{HCl}$ solution to precipitate humic acids and $\mathrm{KCl}$ to flocculate colloids). The content of chloride ions in a material sample elevates the results of the determination of carbon or makes it impossible to determine it due to the reduction of $\mathrm{Cr}^{6+}$ ions (by Cl?) in the oxidising solution (with $\mathrm{K}_{2} \mathrm{Cr}_{2} \mathrm{O}_{7}$ ) during mineralization (KaleMBASA 1991).

\section{RESULTS AND DISCUSSION}

The analyzed substrates were found to contain more dry matter and ash than manure; the $\mathrm{pH}$ was slightly acidic (Table 2). The total carbon content confirms a high potential of substrates for enriching soils with organic matter when used as fertiliser. Nitrogen content (TN) and low values of $\mathrm{C} / \mathrm{N}$ ratio indicate good fertilising properties of the waste material. When added to soil, its narrow $\mathrm{C} / \mathrm{N}$ ratio will positively affect mineralisation of organic matter and release of nutrients contained in substrate. Over $96 \%$ of nitrogen in the analyzed substrates was bound in organic compounds. The reduced ammonium form dominated the mineral nitrogen species (being the result of the ammonification process, which occurs during mushroom cultivation), and oxidised nitric forms were in minority. Other reports (ZMORA-Nahum et al. 2007, Jordan et al. 2008, Kalembasa, MajChrowsKa-Safaryan 2009a, Rutkowska et al. 2009) have indicated certain differentiation of the $\mathrm{C}$ and $\mathrm{N}$ content and $\mathrm{C} / \mathrm{N}$ ratio in spent mushroom substrates, depending on the method of preparation and particularly on the components used in its production.

Some properties of analyzed spent mushroom substrates

\begin{tabular}{|c|c|c|c|c|c|c|c|c|c|c|}
\hline \multirow{2}{*}{$\begin{array}{c}\text { Spent } \\
\text { mushroom } \\
\text { substrate }\end{array}$} & \multirow{2}{*}{$\mathrm{pH}_{\mathrm{KCl}}$} & $\begin{array}{c}\text { Dry } \\
\text { matter }\end{array}$ & Ash & $\mathrm{TC}$ & $\mathrm{TN}$ & \multirow[t]{2}{*}{$\mathrm{TC} / \mathrm{TN}$} & Org-N & Min-N & $\mathrm{N}-\mathrm{NH}_{4}$ & $\mathrm{~N}-\mathrm{NO}_{\mathrm{x}}$ \\
\hline & & $\%$ & \multicolumn{3}{|c|}{$\mathrm{g} \mathrm{kg}^{-1}$ d.m. } & & \multicolumn{2}{|c|}{$\%$ of TN } & \multicolumn{2}{|c|}{$\mathrm{g} \mathrm{kg}^{-1}$ d.m. } \\
\hline A & 6.23 & 30.5 & 400 & 287 & 23.2 & 12.4 & 971 & 201 & 0629 & 0.036 \\
\hline B & 6.29 & 31.8 & 411 & 25 & 19.3 & 13.1 & 96.4 & 369 & 0.676 & 0.025 \\
\hline Mean & - & 31.2 & 406 & 270 & 21.3 & 12.8 & 96.8 & 3.27 & 0.658 & 0.031 \\
\hline
\end{tabular}


The sequential analysis resulted in the isolation (in fractions F1, F2, F3, F4, F5) of about $40 \%$ of total carbon (Table 3). The remaining part is bound in the residual fraction. Based on the average carbon content, the fractions can be arranged by increasing values: F2 $<$ F5 $<$ F1 $\leq$ F3 $<$ F4 $<$ F6. It is noteworthy that a large amount of carbon was extracted by water (F1). Organic carbon extracted with $\mathrm{H}_{2} \mathrm{O}$ and $\mathrm{KNO}_{3}$ (F1 and F2) is probably bound in soluble organic compounds. The fractions are represented mainly by simple, low-molecular organic compounds, loosely bound with mineral components of the analyzed material, potentially readily mineralized and mobile in soil, once they are introduced to soil.

Carbon isolated with solutions commonly used in extraction of humic substances $-\mathrm{Na}_{4} \mathrm{P}_{2} \mathrm{O}_{7}$ and $\mathrm{NaOH}$, (probably) represents part of the organic matter transformed in the process of humification (Tables 3, 4); in fraction F3 - humic substances, free and loosely bound as well as complexed with metals; in F4 - humic substances strongly bound with mineral components of organic material. Carbon of humic acids was found to dominate in those fractions, more markedly in fraction $\mathrm{F} 4$, which is indicated by the values of $\mathrm{C}_{\mathrm{HA}} / \mathrm{C}_{\mathrm{FA}}$ ratio. Prevalence of the humic acid fraction in arable land under

Table 3

Organic carbon fractions in spent mushroom substrates

\begin{tabular}{|c|c|c|c|c|c|c|c|}
\hline \multirow{2}{*}{$\begin{array}{c}\text { Spent } \\
\text { mushroom } \\
\text { substrate }\end{array}$} & \multirow[b]{2}{*}{ Unit } & \multicolumn{5}{|c|}{ Extracted organic carbon } & \multirow{2}{*}{$\begin{array}{l}\mathrm{F} 6 \\
\text { residua }\end{array}$} \\
\hline & & $\begin{array}{c}\mathrm{F} 1 \\
\mathrm{H}_{2} \mathrm{O}\end{array}$ & $\begin{array}{c}\mathrm{F} 2 \\
\mathrm{KNO}_{3}\end{array}$ & $\begin{array}{c}\mathrm{F} 3 \\
\mathrm{Na}_{4} \mathrm{P}_{2} \mathrm{O}_{7}\end{array}$ & $\begin{array}{c}\mathrm{F} 4 \\
\mathrm{NaOH}\end{array}$ & $\begin{array}{c}\mathrm{F} 5 \\
\mathrm{HNO}_{3}\end{array}$ & \\
\hline \multirow{2}{*}{ A } & $\mathrm{g} \mathrm{kg}^{-1}$ & 23.4 & 6.60 & 24.6 & 43.8 & 11.9 & 177 \\
\hline & $\%$ of TC & 8.16 & 2.30 & 8.58 & 15.3 & 4.15 & 61.5 \\
\hline \multirow[t]{2}{*}{ B } & $\mathrm{g} \mathrm{kg}^{-1}$ & 20.9 & 5.25 & 20.2 & 35.1 & 11.0 & 160 \\
\hline & $\%$ of TC & 8.28 & 2.08 & 8.02 & 13.9 & 4.37 & 63.3 \\
\hline \multirow[t]{2}{*}{ Mean } & $\mathrm{g} \mathrm{kg}^{-1}$ & 22.2 & 5.93 & 22.4 & 39.5 & 11.5 & 169 \\
\hline & $\%$ of TC & 8.22 & 2.19 & 8.30 & 14.6 & 4.26 & 62.4 \\
\hline
\end{tabular}

Table 4

Contribution of humic substances carbon (\%) and ratios of humic to fulvic acids carbons

\begin{tabular}{|c|c|c|c|c|c|c|c|c|}
\hline \multirow{3}{*}{$\begin{array}{c}\text { Spent } \\
\text { mushroom } \\
\text { substrate }\end{array}$} & \multirow{3}{*}{$\begin{array}{c}\text { Humic } \\
\text { substances C } \\
\text { F3 + F4 }\end{array}$} & \multicolumn{3}{|c|}{$\begin{array}{c}\mathrm{Na}_{4} \mathrm{P}_{2} \mathrm{O}_{7} \text { extract } \\
\text { F3 }\end{array}$} & \multicolumn{3}{|c|}{$\begin{array}{c}\mathrm{NaOH} \text { extract } \\
\text { F4 }\end{array}$} & \multirow{3}{*}{$\begin{array}{l}\mathrm{C}_{\mathrm{HA}} / \mathrm{C}_{\mathrm{FA}} \\
\text { combined } \\
\text { for humic } \\
\text { substances }\end{array}$} \\
\hline & & $\mathrm{C}_{\mathrm{FA}}$ & $\mathrm{C}_{\mathrm{HA}}$ & \multirow{2}{*}{$\mathrm{C}_{\mathrm{HA}} / \mathrm{C}_{\mathrm{FA}}$} & $\mathrm{C}_{\mathrm{FA}}$ & $\mathrm{C}_{\mathrm{HA}}$ & \multirow{2}{*}{$\mathrm{C}_{\mathrm{HA}} / \mathrm{C}_{\mathrm{FA}}$} & \\
\hline & & \multicolumn{2}{|c|}{$\%$} & & \multicolumn{2}{|c|}{$\%$} & & \\
\hline A & 23.9 & 2.68 & 5.90 & 2.20 & 2.55 & 12.7 & 4.99 & 3.56 \\
\hline B & 21.9 & 2.23 & 5.79 & 2.60 & 2.77 & 11.2 & 4.03 & 3.39 \\
\hline Mean & 22.9 & 2.46 & 5.85 & 2.40 & 2.70 & 12.0 & 4.51 & 3.48 \\
\hline
\end{tabular}


good soil tillage management is a desirable feature of humus, because it ensures its persistence in soil and a more beneficial effect on soil properties. Carbon contained in the residual fraction F6 in spent mushroom cultivation substrates should be regarded mainly as non-humified organic matter (rather than humus). It mostly consists of non-degradable organic waste (mainly cellulose, hemicellulose, lignin), from straw and peat used in the production of substrate and cover. These substances are highly resistant to degradation and persist the longest in soil.

The total content of the analyzed metals (Table 5) confirms that soils fertilised with spent mushroom substrate can be enriched with some nutrients essential for the proper growth and development of plants. As a result, the balance of nutrients in soil cane be improved to the benefit of a better profitability of agricultural production. Chemical analysis showed that the content of selected metals can be listed in the following sequence according to decreasing content: $\mathrm{Ca}>\mathrm{Mg}>\mathrm{Fe}>\mathrm{Mn}>\mathrm{Zn}>\mathrm{Sr}>\mathrm{Ba}>\mathrm{Cu}>\mathrm{Pb}>\mathrm{Cr}$ $>\mathrm{Ni}$. Compared to manure of different origin (MAćKowiAK, ŻEBRowsKi 2000, Mazur, Mokra 2009), (referred to dry weight and the element), spent mushroom substrates had a much higher content of $\mathrm{Ca}$ (about 30-fold more) and $\mathrm{Mg}$ (about 3-fold more) as well as a similar content of $\mathrm{Fe}, \mathrm{Mn}, \mathrm{Zn}$ and $\mathrm{Cu}$. The heavy metal content did not exceed the permissible values for fertilisers and plant growth enhancers, which can be used as fertilisers in agriculture (Regulation... 2008).

Owing to the extraction procedure applied in the study, it was possible to determine the metal content in potentially bioavailable and mobile (soluble) forms, bound to a different extent with organic matter. Sequential use of extraction reagents with an increasing ability to separate carbon and metal compounds $\left(\mathrm{H}_{2} \mathrm{O} \rightarrow \mathrm{KNO}_{3} \rightarrow \mathrm{Na}_{4} \mathrm{P}_{2} \mathrm{O}_{7} \rightarrow \mathrm{NaOH} \rightarrow \mathrm{HNO}_{3} \rightarrow\right.$ aqua regia), allows us to list fractions of the elements according to the increasing resistance to biodegradation: F1 > F2 > F3 > F4 > F5 > F6. In heavy metals, it allows us to evaluate the current and potential hazard to the environment (phytoavailability, mobility).

Metals contained in the spent mushroom substrates have different properties and a different status in the biosphere: $\mathrm{Mg}$ and $\mathrm{Ca}$ - main bioelements; $\mathrm{Fe}, \mathrm{Mn}, \mathrm{Zn}, \mathrm{Cu}, \mathrm{Ni}$ - trace bioelements, essential to plants, humans and animals; $\mathrm{Cr}$ - a trace bioelement, essential to humans and animals; $\mathrm{Pb}$ - trace element with high toxicity to humans, and $\mathrm{Sr}$ and $\mathrm{Ba}$ - trace elements which have not been found to be essential to organisms.

When using spent substrate as fertiliser and for potential migration of elements and eutrophication of the environment when it is stored, the water-soluble fraction F1 (bioavailable and easily leachable), the exchangeable fraction F2 (where desorption to a solution is possible) and fraction F3 (metals in complexes with organic compounds, relatively mobile and potentially bioavailable) are of special importance (Hsu, Lo 2000). 
Total content and fractions of some elements in spent mushroom substrates

\begin{tabular}{|c|c|c|c|c|c|c|c|c|}
\hline \multirow[b]{2}{*}{ Element } & \multirow{2}{*}{$\begin{array}{c}\text { Spent } \\
\text { mushroom } \\
\text { substrate }\end{array}$} & \multirow{2}{*}{$\begin{array}{c}\text { Total } \\
\text { content } \\
\text { (sum of } \\
\text { fractions) } \\
\left(\mathrm{mg} \mathrm{kg}^{-1}\right)\end{array}$} & \multicolumn{6}{|c|}{ Content of element fractions ( $\mathrm{mg} \mathrm{kg}^{-1}$ ) } \\
\hline & & & $\begin{array}{c}\mathrm{F} 1 \\
\mathrm{H}_{2} \mathrm{O}\end{array}$ & $\begin{array}{c}\mathrm{F} 2 \\
\mathrm{KNO}_{3}\end{array}$ & $\begin{array}{c}\mathrm{F} 3 \\
\mathrm{Na}_{4} \mathrm{P}_{2} \mathrm{O}_{7}\end{array}$ & $\begin{array}{c}\mathrm{F} 4 \\
\mathrm{NaOH}\end{array}$ & $\begin{array}{c}\mathrm{F} 5 \\
\mathrm{HNO}_{3}\end{array}$ & $\begin{array}{c}\mathrm{F} 6 \\
\text { residual }\end{array}$ \\
\hline \multirow{2}{*}{$\mathrm{Mg}$} & A & 3320 & 619 & 961 & 431 & 48.0 & 1190 & 77.0 \\
\hline & B & 2910 & 557 & 837 & 266 & 38.0 & 1120 & 91.0 \\
\hline \multirow{2}{*}{$\mathrm{Ca}$} & A & 88100 & 2620 & 13800 & 2040 & 948 & 68100 & 569 \\
\hline & B & 113000 & 2970 & 16900 & 1420 & 936 & 89700 & 518 \\
\hline \multirow{2}{*}{$\mathrm{Fe}$} & A & 2710 & 9.00 & 11.0 & 442 & 176 & 1450 & 618 \\
\hline & B & 2110 & 16.0 & 11.0 & 300 & 137 & 1240 & 401 \\
\hline \multirow{2}{*}{ Mn } & A & 321 & 6.30 & 10.6 & 45.1 & 8.25 & 245 & 5.52 \\
\hline & B & 260 & 6.83 & 12.9 & 37.7 & 5.64 & 193 & 4.08 \\
\hline \multirow{2}{*}{$\mathrm{Sr}$} & A & 82.9 & 3.15 & 12.7 & 0.890 & 0.290 & 64.6 & 1.31 \\
\hline & B & 112 & 3.51 & 15.3 & 0.754 & 0.232 & 90.7 & 1.10 \\
\hline \multirow{2}{*}{$\mathrm{Ba}$} & A & 45.1 & 0.499 & 4.31 & 0.716 & 1.03 & 36.3 & 2.24 \\
\hline & B & 55.5 & 0.648 & 6.86 & 0.265 & 0.900 & 44.7 & 2.08 \\
\hline \multirow{2}{*}{$\mathrm{Zn}$} & A & 180 & 2.63 & 3.23 & 122 & 4.94 & 37.6 & 9.44 \\
\hline & B & 148 & 2.54 & 2.81 & 94.0 & 5.00 & 34.8 & 8.70 \\
\hline \multirow{2}{*}{$\mathrm{Cu}$} & A & 21.6 & 0.845 & 0.902 & 5.03 & 7.18 & 6.57 & 1.11 \\
\hline & B & 18.6 & 0.622 & 0.885 & 3.85 & 6.03 & 6.46 & 0.714 \\
\hline \multirow{2}{*}{$\mathrm{Ni}$} & A & 3.33 & 0.214 & 0.100 & 0.631 & 0.383 & 1.05 & 0.949 \\
\hline & B & 2.88 & 0.155 & 0.125 & 0.539 & 0.244 & 0.865 & 0.950 \\
\hline \multirow{2}{*}{$\mathrm{Cr}$} & A & 4.56 & 0.095 & 0.113 & n. d. & n. d. & 0.743 & 3.61 \\
\hline & B & 4.96 & 0.150 & 0.160 & n. d. & n. d. & 1.04 & 3.61 \\
\hline \multirow{2}{*}{$\mathrm{Pb}$} & A & 4.30 & 0.110 & 0.212 & 0.496 & 0.210 & 2.74 & 0.534 \\
\hline & B & 5.32 & 0.090 & 0.223 & 0.580 & 0.400 & 3.38 & 0.657 \\
\hline
\end{tabular}

n.d. - not determinated

Speciation variability between the analysed metals and similarities in the presence of metals in fractions have been found between the analyzed mushroom cultivation substrates (Tables 5, 6). A decreasing content of metals in the isolated fractions is shown in sequences for Mg: F5 > F2 $>$ F1 > F3 $>$ F6 > F4; Ca: F5 > F2 > F1 > F3 $\geq$ F4 = F6; Fe: F5 $>$ F6 $>$ F3 $>$ F4 $>$ F1 $\geq$ F2; Mn: F5 $>$ F3 $>$ F4 $>$ F2 $>$ F1 $>$ F6; Zn: F3 $>$ F5 $>$ F6 $>$ F4 $>$ F2 $\geq \mathrm{F} 1$; $\mathrm{Cu}: \mathrm{F} 4 \geq \mathrm{F} 5>\mathrm{F} 3>\mathrm{F} 6>\mathrm{F} 2>\mathrm{F} ; \mathrm{Ni}: \mathrm{F} 5 \geq \mathrm{F} 6>\mathrm{F} 3>\mathrm{F} 4>\mathrm{F} 1>$ 
Table 6

Contribution of separated fractions of elements (mean for spent mushroom substrates)

\begin{tabular}{|c|c|c|c|c|c|c|}
\hline \multirow{2}{*}{ Element } & \multicolumn{7}{|c|}{ Fractions $(\%)$} \\
\cline { 2 - 7 } & $\begin{array}{c}\mathrm{F} 1 \\
\mathrm{H}_{2} \mathrm{O}\end{array}$ & $\begin{array}{c}\mathrm{F} 2 \\
\mathrm{KNO}_{3}\end{array}$ & $\begin{array}{c}\mathrm{F} 3 \\
\mathrm{Na}_{4} \mathrm{P}_{2} \mathrm{O}_{7}\end{array}$ & $\begin{array}{c}\mathrm{F} 4 \\
\mathrm{NaOH}\end{array}$ & $\begin{array}{c}\mathrm{F} 5 \\
\mathrm{HNO}_{3}\end{array}$ & $\begin{array}{c}\mathrm{F} 6 \\
\text { residual }\end{array}$ \\
\hline $\mathrm{Mg}$ & 18.9 & 28.8 & 11.1 & 1.38 & 37.2 & 2.73 \\
\hline $\mathrm{Ca}$ & 2.81 & 15.4 & 1.79 & 0.955 & 78.6 & 0.56 \\
\hline $\mathrm{Fe}$ & 0.54 & 0.46 & 15.3 & 6.50 & 56.3 & 20.9 \\
\hline $\mathrm{Mn}$ & 2.30 & 4.14 & 14.3 & 2.37 & 75.3 & 1.65 \\
\hline $\mathrm{Sr}$ & 3.47 & 14.5 & 0.88 & 0.28 & 79.6 & 1.28 \\
\hline $\mathrm{Ba}$ & 1.14 & 11.0 & 1.04 & 1.96 & 80.6 & 4.36 \\
\hline $\mathrm{Zn}$ & 1.60 & 1.85 & 65.7 & 3.07 & 22.3 & 5.57 \\
\hline $\mathrm{Cu}$ & 3.63 & 4.47 & 22.0 & 32.9 & 32.6 & 4.50 \\
\hline $\mathrm{Ni}$ & 5.91 & 3.68 & 18.9 & 9.99 & 30.8 & 30.8 \\
\hline $\mathrm{Cr}$ & 2.56 & 2.85 & n.w. & n.w. & 18.6 & 76.0 \\
\hline $\mathrm{Pb}$ & 2.13 & 4.56 & 11.2 & 6.21 & 63.6 & 12.4 \\
\hline
\end{tabular}

F2; Cr: F6 $>$ F5 $>$ F2 $\geq$ F1 (w F3 and F4 not found); Pb: F5 $>$ F6 $>$ F3 $>$ F4 > F2 > F1; Sr: F5 > F2 > F1 > F6 $\geq$ F3 $\geq$ F4; Ba: F5 > F2 > F6 > F4 $\geq \mathrm{F} 1 \geq \mathrm{F} 3$.

Most of the metals $(\mathrm{Ba}>\mathrm{Sr}>\mathrm{Ca}>\mathrm{Mn}>\mathrm{Pb}>\mathrm{Fe}>\mathrm{Mg}>\mathrm{Ni})$ were bound strongly with organic and mineral compounds of the mushroom substrates (fraction F5). The fraction dominated especially in the case of $\mathrm{Ba}, \mathrm{Sr}$ and $\mathrm{Ca}$, which are similar metals and co-occur in the environment. The main source of these elements in mushroom substrates are additives, usually added as carbonates, which raise the $\mathrm{pH}$ value at the stage of substrate and cover production. A characteristic feature of $\mathrm{Ca}, \mathrm{Sr}, \mathrm{Ba}$ and $\mathrm{Mg}$ was their considerably high content in the exchangeable fraction F2. A positive property of the substrates is that the heavy metals $\mathrm{Pb}$ and $\mathrm{Cr}$ dominated in stable fractions F5 and F6 and were present only in small quantities in F1 and F2 (potentially bioavailable fractions). An analogously low content of heavy metals in extracts $\left(\mathrm{H}_{2} \mathrm{O}\right.$ and $\mathrm{CaCl}_{2}$ solution) from manure and composts was found by GoNDEK (2007). Unlike other metals, chromium was bound in the residual fraction $\mathrm{F} 6$ to the greatest extent - actually, it was not found in compounds with humic substances in fractions F3 and F4. More than half of the amount of $\mathrm{Zn}$ and $\mathrm{Cu}$ was bound in those fractions (F3, F4), and $\mathrm{Ni}, \mathrm{Fe}, \mathrm{Pb}$ and $\mathrm{Mn}$ were present at $16.7-28.8 \%$ (Table 7), mainly in the fraction complexed with humic substances (F3) or- in the case of $\mathrm{Cu}$ - metals bound by humic substances (F4). 
Table 7

Contribution of fractions of fulvic and humic acids bounded metals

\begin{tabular}{|c|c|c|c|c|}
\hline \multirow{2}{*}{ Element } & \multicolumn{2}{|c|}{$\mathrm{Fa}_{4} \mathrm{P}_{2} \mathrm{O}_{7}$} & \multicolumn{2}{c|}{$\mathrm{F} 4$} \\
\cline { 2 - 5 } & $\mathrm{F} 3_{\mathrm{FA}}$ & $\mathrm{F}_{\mathrm{HA}}$ & $\mathrm{F}_{\mathrm{FA}}$ & ${ } 4_{\mathrm{HA}}$ \\
\hline $\mathrm{Mg}$ & 86.6 & 13.4 & 87.0 & 13.0 \\
\hline $\mathrm{Ca}$ & 85.8 & 14.2 & 91.6 & 8.38 \\
\hline $\mathrm{Fe}$ & 75.4 & 24.6 & 81.7 & 18.3 \\
\hline $\mathrm{Sr}$ & 78.4 & 21.6 & 83.3 & 16.7 \\
\hline $\mathrm{Ba}$ & 66.5 & 33.5 & 36.5 & 63.5 \\
\hline $\mathrm{Mn}$ & 76.6 & 23.4 & 88.4 & 11.6 \\
\hline $\mathrm{Zn}$ & 76.0 & 24.0 & 70.4 & 29.6 \\
\hline $\mathrm{Cu}$ & 20.6 & 79.4 & 14.0 & 86.0 \\
\hline $\mathrm{Ni}$ & 1.00 & 99.0 & 18.3 & 81.7 \\
\hline $\mathrm{Pb}$ & 81.3 & 18.7 & 41.0 & 59.0 \\
\hline
\end{tabular}

The majority of the metals in the humic substance fractions were found in the fulvic acid fractions $\left(\mathrm{F}_{\mathrm{FA}}\right.$ i $\left.\mathrm{F} 4_{\mathrm{HA}}\right)$. The significance of humic acids (a more stable fraction of humic substances) was higher for speciation of $\mathrm{Cu}$ and $\mathrm{Ni}$, and slightly weaker for $\mathrm{Ba}$ and $\mathrm{Pb}$ (in $\mathrm{F} 4_{\mathrm{HA}}$ ).

\section{CONCLUSIONS}

1. Spent mushroom substrate should be used as fertiliser because of its high potential for enriching soil with organic compounds. Moreover, it contains much more $\mathrm{Ca}$ and $\mathrm{Mg}$ than manure and comparable amounts of micronutrients.

2. The highest amounts of carbon in the substrates (62\%) were bound with the stable residual fraction, while $10 \%$ was present in the bioavailable fractions.

3. The content of the metals in the fractions varied, with most of them $(\mathrm{Ba}>\mathrm{Sr}>\mathrm{Ca}>\mathrm{Mn}>\mathrm{Pb}>\mathrm{Fe}>\mathrm{Mn}>\mathrm{Ni})(80.6-30.8 \%$ of the total content) being strongly bound with organic and mineral compounds (fraction F5).

4. Considerable amounts of $\mathrm{Ca}, \mathrm{Mg}, \mathrm{Mn}, \mathrm{Sr}, \mathrm{Fe}$ and $\mathrm{Zn}$ were bound with fulvic acids and $\mathrm{Cu}, \mathrm{Ni}, \mathrm{Ba}$ and $\mathrm{Pb}$ - with more stable humic acids. The fractions bound with humic substances (F3 and F4) were of the highest quantitative importance in speciation of zinc and copper. 
5. It would be advisable to carry out further studies of speciation of metals bound with organic compounds in waste organic materials with respect to their environmental hazard and potential use as fertilisers.

\section{REFERENCES}

Dziadowiec H., Gonet S.S. 1999. A guidebook of methodology for research on organic matter. Pr. Kom. Nauk. PTG, 120,Warszawa. (in Polish)

GoNDEK K. 2007. Content of carbon, nitrogen and selected heavy metals in composts. J. Elementol., 12 (1): 13-23.

He X.T., Logan T. L., Traina S. J. 1995. Physical and chemical characteristics of selected U.S. municipal solid waste composts. J. Environ. Qual., 24: 543-552.

Hsu J.H., Lo S.L. 2001. Effect of composting on characterization and leaching of copper, manganesse, and zinc from swine manure. Environ. Pollut.,114: 119-127.

Jordan S.N., Mullen G.J., MurPhy M.C. 2008. Composition variability of spent mushroom compost In Ireland. Biores. Technol., 99: 411-418.

Kalembasa D., Majchrowska-Safaryan A. 2009a. Nutrient abundance of spent mushroom substrate. Zesz. Probl. Post. Nauk Rol., 535: 195-200. (in Polish)

Kalembasa D., Majchrowska-Safaryan A. 2009b. Fractions of heavy metals in spent mushroom substrates. Ochr. Środ. Zas. Nat., 41: 572-577. (in Polish)

Kalembasa S. 1991. Quick method of determination of organic carbon in soil. Pol. J. Soil Sci., 24(1): 17-22.

Maćkowiak C. Żebrowski J. 2000. Chemical composition of manure in Poland. Nawozy i Nawożenie, 4(5): 119-130. (in Polish)

Mazur Z., Mokra O. 2009. Concentration of macronutrients in natural fertilizers in Poland in 2003-2005. Zesz. Probl. Post. Nauk Rol., 537: 243-247. (in Polish)

Medina E., Paredes C., Perez-Muria M.D., Bustamante M.A., Moral R. 2009. Spent mushroom substrates as component of growing media for germination and growth of horticultural plamts. Biores. Technol., 100: 4227-4232.

Regulation of the Minister for Agriculture and Rural Development of 18 June 2008. Journal of Law 119 item 765. (in Polish)

Rutkowska B., Szulc W., StęPień W., Jobda J. 2009. Possible use of spent mushroom substrates in agriculture. Zesz. Probl. Post. Nauk Rol., 535: 349-356. (in Polish)

Stewart D.P.C., Cameron K.C., Confort I.S. 1998. Effect of spent mushrum substrate on soil chemical conditions and plant growth in an intensive horticultural system: a comparison with inorganic fertiliser. Austr. J. Soil Res., 36(2): 75-83.

Zmora-Nahum S., Hadar Y., Chen Y. 2007. Physico-chemical properties of commercial composts varying in their Skurce materials and country of origin. Soil Biol. Biochem., 39: $1263-1276$. 